\title{
Effects of the COVID-19 pandemic on an urban cervical cancer screening program in West Cameroon
}

\author{
Jessica Sormani (D) , Geneva, Switzerland, Geneva, Switzerland; Alida Moukam Datchoua, Dschang, Cameroon; \\ Patrick Petignat, Geneva, Switzerland; Bruno Kenfack, Dschang, Cameroon and Nicole C Schmidt, Geneva, \\ Switzerland, Munich, Germany
}

\section{INTRODUCTION}

Cervical cancer is the fourth most common cancer among women worldwide, and in 2020 almost $85 \%$ of new cases occurred in low and middle income countries. In Cameroon, 1787 deaths were recorded in 2020, making cervical cancer the second most common cause of cancer deaths among women. Recently, in 2020, the World Health Organization (WHO) launched the 90-70-90 strategy to eliminate cervical cancer (box 1).

In response, the Dschang District Hospital, the Cameroon Ministry of Public Health, and the Geneva University Hospitals launched a community based cervical cancer screening program ('3T-approach': test, triage, and treat) at the Dschang District Hospital in West Cameroon. The program has been presented in this journal previously.

\section{EFFECT OF THE COVID-19 PANDEMIC}

Although the WHO considered cervical cancer prevention activities a priority during the COVID-19 pandemic, the Dschang cervical cancer primary screening program and follow-up procedures were substantially affected, as were many preventive health services worldwide. From mid-March until the end of April 2020, the screening unit was closed as it was considered inappropriate to expose women and healthcare providers to the risk of COVID-19. In May 2020, follow-up visits were progressively restarted after implementation of the necessary hygiene measures to control the spread of the virus and ensure the safety of the facilities. Consequently, the number

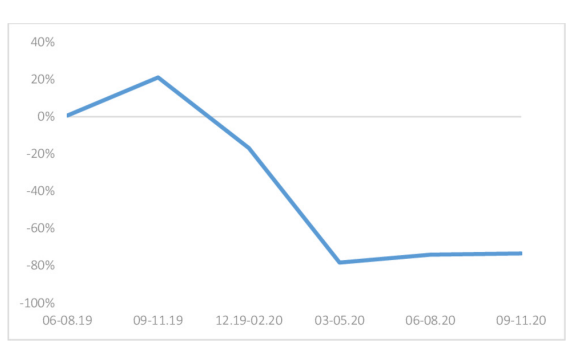

Figure 1 Percentage change in visit 1 from baseline (average of 109 visits/ month in 2019) due to the COVID-19 pandemic.

of women screened in 2020 dropped by almost $80 \%$ compared with the same period in 2019 (Figure 1). To reduce the risk of exposure between patients and staff, (i) the number of patients attending the clinic was reduced, (ii) physical distancing between patients was implemented, (iii) mask wearing (Figure 2) and (iv) regular hand washing with soap or disinfection with gel was required, as well as (v) careful hygiene regarding equipment and surfaces.

However, as the local health authorities have made substantial efforts in the past few years to launch the cervical cancer program, it was feared that an extended closure of the program might endanger its perennity. Therefore, in July 2020, the cervical cancer screening activities were progressively relaunched. Following the preventative hygienic measures during the COVID-19 pandemic, a major advantage of the program is that human papillomavirus (HPV) based screening can be performed by women themselves (HPV self-sampling). As no pelvic examination is needed, the risk of

\section{Box 1 Global strategy to eliminate cervical cancer 2020-2030}

\footnotetext{
- $90 \%$ vaccination coverage of girls

- $70 \%$ screening coverage

- $90 \%$ access to treatment for precancerous and cancerous lesions
}

exposure between patients and providers remains low.

\section{EMERGING BARRIERS TO CERVICAL CANCER SCREENING}

However, despite major efforts to ensure patient safety, new barriers to cervical cancer screening emerged during the

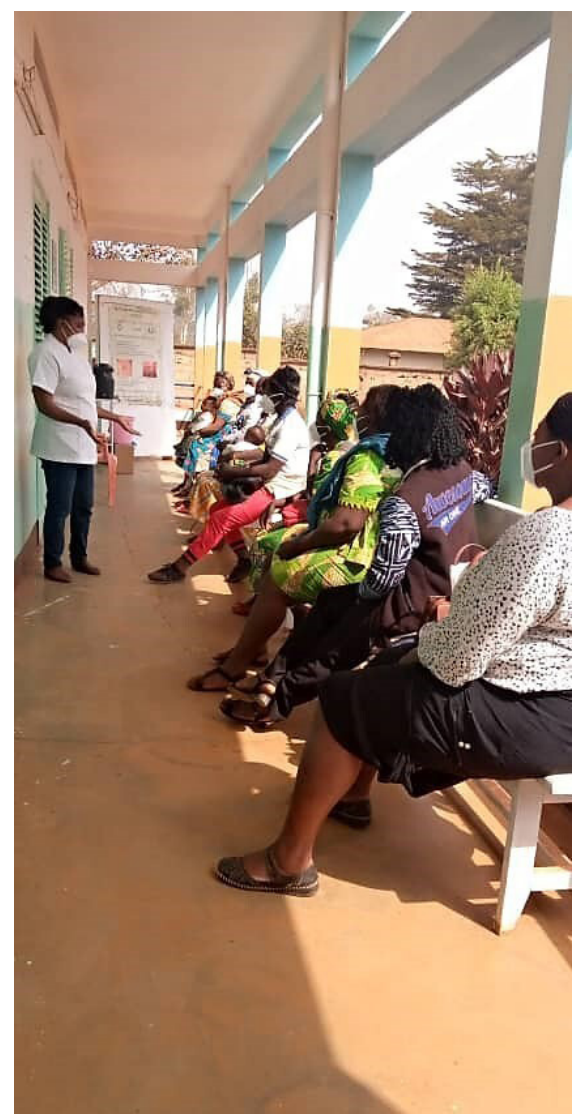

Figure 2 Teaching about women's health and cervical cancer by midwifes to patients in the parlor. This space is located outside, allowing social distancing between women and everyone interested in assisting and learning about the benefits of the screening program and women's health, and who can then spread the information to others. 


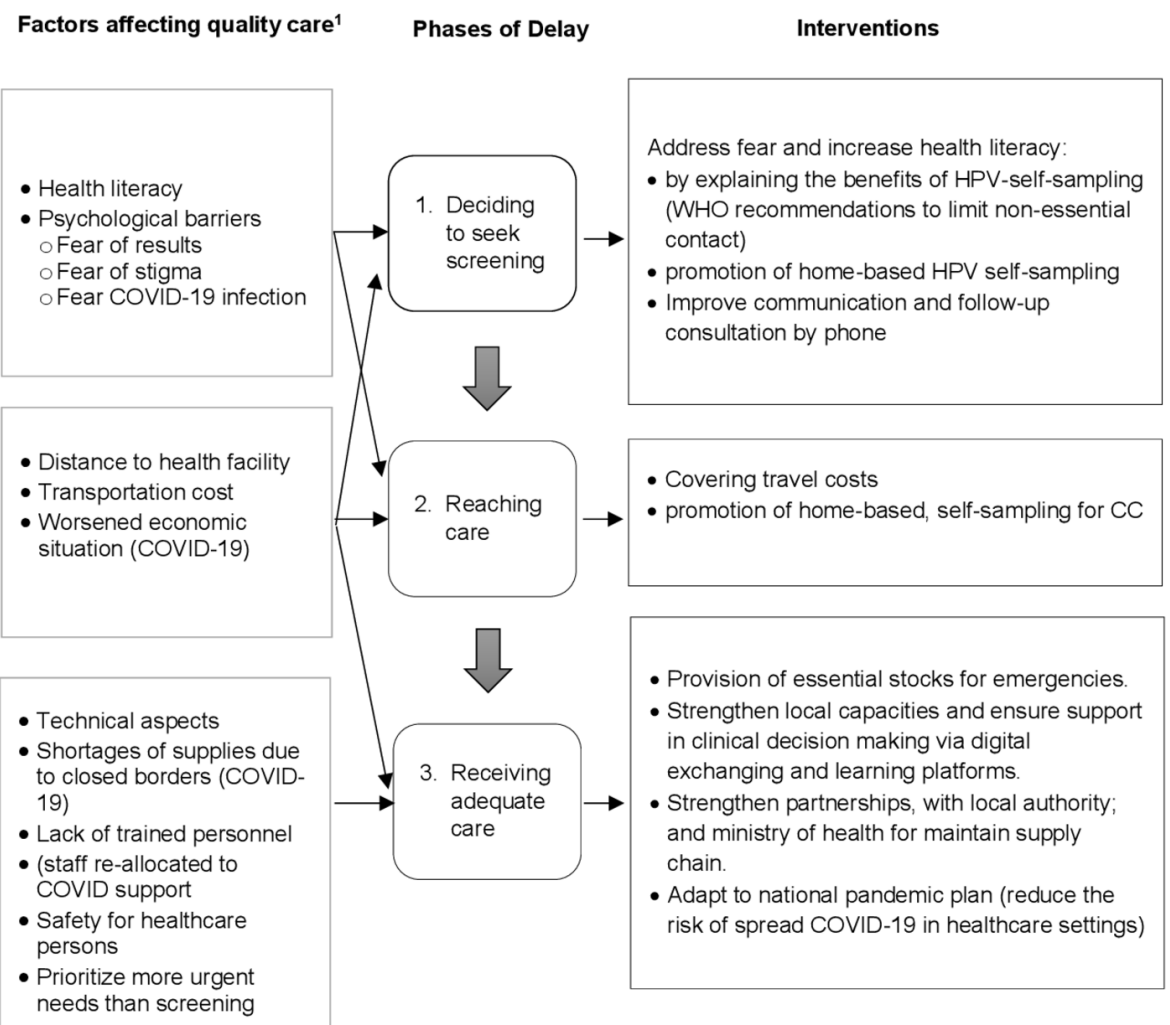

Figure 3 Responses to the three delay model applied to human papillomavirus (HPV) screening (Thaddeus S, Maine D. Soc Sci Med. Vol 38. No. 8, pp. 1091-1110, 1994). The decision to seek care, such as screening, is not subject to the same barriers to access to care as it is for follow-up. Follow-up is not impacted by the first delay and is therefore not taken into account in this analysis.

COVID-19 pandemic. The conceptual framework of Thaddeus and Maine's three delay model has been used to describe these barriers and highlight those that newly appeared owing to the COVID-19 pandemic. The model describes factors that delay the process of seeking healthcare according to three critical phases (first delay, family and community factors; second delay, factors related to accessibility; and third delay: services provided at the healthcare facility).

The analysis shows that existing factors affecting women's health seeking behavior remained and new barriers appeared (Figure 3). Importantly, new patient related obstacles emerged, such as less access to health facilities. Also, health system barriers appeared because health services were unavailable owing to closure or stockouts as supply chains were affected. These findings are in line with recently published studies and highlight the importance of a multisectoral approach to reduce negative effects on women's sexual and reproductive health.
In settings where efficient hygiene measures to avoid COVID-19 transmission can be implemented, cervical cancer screening activities should be maintained and new emerging barriers addressed. For the Dschang cervical cancer program, three important key actions were identified: (1) coverage of transportation costs for women accepting cervical cancer screening at the Dschang District Hospital, (2) improvement of pandemic related health literacy, and (3) introduction of home based HPV selfsampling to reduce the risk of exposure at the hospital or during travel.

Correspondence to Jessica Sormani, Geneva School of Health Science, HESSO University of Applied Sciences and Arts Western Switzerland, Geneva 1205, Switzerland; jessica.sormani@hcuge.ch

Acknowledgements The authors thank Ania Wisniak, Jovanny Tsuala Fouogue, Penga Abanda Helena, Limofack Jeanne Benitte, Abatsong Esther, Ndam Nsangou Francois Marcel, Tiheho Goguin Eveline, Engelbert Manga, and Pierre Vassilakos. The authors thank Diane Williams, PhD, from the Edanz Group (https://en-author-services.edanz.com/ac) for editing a draft of the manuscript.
Collaborators Ania Wisniak, Jovanny Tsuala Fouogue, Penga Abanda Helena, Limofack Jeanne Benitte, Abatsong Esther, Ndam Nsangou Francois Marcel, Tiheho Goguin Eveline, Engelbert Manga, Pierre Vassilakos.

Contributors All of the authors made contributions to the design and participated in drafting and revising the manuscript. All authors gave final approval of the submitted version.

Funding The research was supported by the Humanitarian Affair Commission of the Geneva University Hospitals, Solidarité Internationale (Canton of Geneva), and Fondation Privée des HUG. The authors have not declared a specific grant for this research from commercial sectors.

Competing interests None declared.

Patient consent for publication Not required.

Provenance and peer review Commissioned; internally peer reviewed.

Supplemental material This content has been supplied by the author(s). It has not been vetted by BMJ Publishing Group Limited (BMJ) and may not have been peer-reviewed. Any opinions or recommendations discussed are solely those of the author(s) and are not endorsed by BMJ. BMJ disclaims all liability and responsibility arising from any reliance placed on the content. Where the content includes any translated material, BMJ does not warrant the accuracy and reliability of the translations (including but not limited to local regulations, clinical guidelines, terminology, drug names and drug dosages), and is not responsible for any error and/or omissions arising from translation and adaptation or otherwise.

\section{(a) OPEN ACCESS}

Open access This is an open access article distributed in accordance with the Creative Commons Attribution Non Commercial (CC BY-NC 4.0) license, which permits others to distribute, remix, adapt, build upon this work non-commercially, and license their derivative works on different terms, provided the original work is properly cited, an indication of whether changes were made, and the use is non-commercial. See: http://creativecommons.org/ licenses/by-nc/4.0/.

(C) IGCS and ESG0 2021. Re-use permitted under CC BY-NC. No commercial re-use. Published by BMJ.

\section{Check for updates}

To cite Sormani J, Datchoua AM, Petignat P, et al. Int J Gynecol Cancer 2021;31:1297-1298.

Accepted 23 February 2021

Published Online First 12 March 2021

Int J Gynecol Cancer 2021;31:1297-1298.

doi:10.1136/ijgc-2021-002555

ORCID iD

Jessica Sormani http://orcid.org/0000-0001-71113975 